\title{
PENGARUH EKSPEKTASI PENDAPATAN TERHADAP MINAT BERWIRAUSAHA PADA MASYARAKAT (STUDI KASUS PADA DESA TUMPATAN NIBUNG DUSUN VI KECAMATAN BATANG KUIS KABUPATEN DELI SERDANG SUMATERA UTARA
}

\author{
${ }^{1}$ Rizky Setiawan, ${ }^{2}$ Abdul Malik \\ ${ }^{1,2}$ Universitas Muslim Nusantara Al-Washliyah Medan \\ ${ }^{1}$ rizkysetiawan112020@gmail.com, ${ }^{2}$ abdul.malik@gmail.com
}

\begin{abstract}
This study aims to determine the effect of income expectations on entrepreneurial interest in the people of Tumpatan Nibung Village VI Dusun VI, Batang Kuis District, Deli Serdang Regency. The sampling technique used was random sampling method, namely taking samples from the population at random without regard to the strata in the population of 94 people. Methods of data collection using a questionnaire. In the partial hypothesis test ( $t$ test) the income expectation variable has a positive and significant effect on the interest in entrepreneurship with a $t$ count $>t$ table $(9.969>1.661)$ and a significant value of $0.000<0.05$. The results of the determination test obtained an $R$ Square value of 0.519 , meaning that the variable interest in entrepreneurship can be explained by $51.9 \%$ by the income expectation variable, while the remaining $48.1 \%$ is explained by other variables not included in this study.
\end{abstract}

Keywords: Income Expectations and Interest in Entrepreneurship

ABSTRAK : Penelitian ini bertujuan untuk mengetahui pengaruh ekspektasi pendapatan terhadap minat berwirausaha pada masyarakat Desa Tumpatan Nibung Dusun VI Kecamatan Batang Kuis Kabupaten Deli Serdang. Teknik pengambilan sampel menggunakan metode random sampling, yaitu pengambilan sanggota sampel dari populasi dilakukan secara acak tanpa memperhatikan strata yang ada dalam populasi berjumlah 94 orang. Metode pengumpulan data menggunakan kuesioner. Pada uji hipotesis parsial (Uji t) variabel ekspektasi pendapatan berpengaruh positif dan signifikan terhadap minat berwirausaha dengan nilai $t$ hitung $>t$ tabel $(9,969>1,661)$ dan nilai signifikan 0,000 < 0,05. Hasil uji determinasi diperoleh nilai $R$ Square sebesar 0,519, artinya variabel minat berwirausaha dapat dijelaskan sebesar 51,9\% oleh variabel ekspektasi pendapatan, sementara sisanya $48,1 \%$ dijelaskan oleh variabel lain yang tidak dimasukkan dalam penelitian ini.

Kata Kunci : ekspetasi pendpatan dan minat berwiarusaha.

\section{Pendahuluan}

Prestasi kerja adalah suatu hasil kerja yang dicapai seseorang dalam melaksanakan tugastugas yang Minat berwirausaha dapat menimbulkan dorongan dan keinginan untuk berusaha atau menjalankan suatu bisnis. Minat berwirausaha dapat mendorong seseorang untuk bekerja keras, berani mengambil dan menanggung segala risiko, bersedia keluar dari zona nyaman dan lebih memilih menempuh jalan atau cara baru yang lebih efisien, bersedia untuk hidup hemat serta menjadikan pengalaman sebagai pembelajaran untuk mencapai kesuksesan. Minat berwirausaha tidak tumbuh dengan bergitu saja, melainkan harus ditanam dan dikembangkan dalam diri seseorang. Dengan adanya minat untuk memulai usaha, maka seseorang akan lebih memiliki keinginan untuk maju pada usaha yang diajalakannya dibandingkan dengan orang yang kurang memiliki minat untuk memulai usaha.

Minat menunjukkan apa yang ingin dicapai atau ingin dilakukan oleh seseorang yang pada dasarnya berasal dari apa yang ia senangi. Minat ini dapat dikembangkan dengan adanya harapan atau ekspektasi pendapatan dari berwirausaha itu sendiri. Ekspektasi pendapatan dalam hal ini merupakan harapan seseorang atas pendapatan yang diterimanya baik berupa uang maupun barang guna untuk memenuhi kebutuhan hidupnya. Dengan menekuni dunia 
kewirausahaan, hal ini akan mampu menjamin dalam menghasilkan pendapatan yang tinggi. Sekalipun pendapatan dari dunia wirausaha tidak mungkin dapat diprediksi, terkadang pendapatan yang diperoleh sesuai dengan yang diharapkan, kadang juga pendapatannya jauh dari yang diharapkan tapi semuanya itu tergantung pada sejauh mana usaha yang dilakukan.

Suatu ekspektasi atau harapan untuk mendapatkan penghasilan yang tinggi menjadi salah satu faktor penting, yang dapat mempengaruhi seseorang memutuskan untuk segera memulai berwirausaha atau tidak. Jika seseorang berharap untuk mendapatkan pendapatan yang lebih tinggi dengan menjadi wirausaha, maka ia akan semakin terdorong untuk menjadi seorang wirausaha. Semakin tinggi pendapatan seseorang didalam berwirausaha maka akan semain tinggi juga minatnya untuk meneruskan wirausahanya tersebut. Dan sebaliknya jika pendapatannya rendah maka minat untuk melakukan wirausaahanya tersebutpun akan semakin berkurang.

Seseorang yang berwirausaha dengan baik akan mendatangkan pendapatan yang besar dan tidak terbatas, walaupun pendapatan dari berwirausaha tersebut tidak bisa diprediksi, kadang bisa diatas pendapatan yang diharapkanya, kadang pula bisa diluar dari yang pendapatan diharapkanya. Tinggi rendahnya pendapatan yang diterima tergantung pada besar tidaknya usaha yang kita lakukan dalam menjalankan kegiatan tersebut. Seseorang dengan ekspektasi pendapatan berwirausahaa yang lebih tinggi daripada bekerja menjadi karyawan merupakan daya tarik untuk menjadi wirausaha. Karena salah satu alasan seseorang berminat berwirausaha karena berwirausaha memiliki kemungkinan menghasilkan pendapatan yang lebih tinggi daripada karyawan.

Bila diperhatikan dari data tersebut diatas, semua jenis usaha di Dusun VI Desa Tumpatan Nibung tergolong ke dalam jenis usaha mikro. UMKM yang jumlahnya sangat sedikit menunjukkan bahwa minat berwirausaha masyarakat Dusun VI Desa Tumpatan Nibung tergolong rendah. Bila diperhatikan dari masyarakat Dusun VI yang jumlah jiwanya mencapai 1.713 jiwa sedangkan UMKM yang ada hanya 9 sangat jelas sekali bahwa masyarakat tidak memiliki minat dalam berwirausaha karena jumlah UMKM yang ada berbanding jauh dengan jumlah masyarakat. Sedangkan menurut masyarakat Dusun VI pendapatan dari berwirausaha tergolong rendah dan tidak menentu apalagi usaha yang baru dibangun dari bawah, belum lagi resikonya cukup besar dimana segala bentuk kerugian yang dihadapi akan ditanggung sendiri. Selain itu masyarakat juga menyatakan bahwa menjadi wirausahawan itu tidak mudah butuh pengetahuan yang lebih dan modal yang banyak untuk memulai usaha, sedangkan untuk mendapatkan kebutuhan sehari-hari saja sudah sudah dari mana modal untuk berwirausaha. Dari uraian diatas, maka penulis akan melakukan penelitian dengan judul: "Pengaruh Ekspektasi Pendapatan Terhadap Minat Berwirausaha Pada Masyarakat (Studi Kasus Pada Desa Tumpatan Nibung Dusun VI Kecamatan Batang Kuis Kabupaten Deli Serdang Sumatera Utara)".

\subsection{Rumusan Masalah}

Rumusan masalah menurut Arikunto (2016:36) adalah pernyataan rinci dan lengkap mengenai ruang lingkup permasalahan yang akan diteliti berdasarkan identifikasi masalah. Adapun rumusan masalah dalam penelitian ini adalah sebagai berikut:

1. Apakah ekspektasi pendapatan berpengaruh terhadap minat berwirausaha pada masyarakat Desa Tumpatan Nibung Dusun VI Kecamatan Batang Kuis Kabupaten Deli Serdang Sumatera Utara?

2. Seberapabesar ekspektasi pendapatan berpengaruh terhadap minat berwirausaha pada masyarakat Desa Tumpatan Nibung Dusun VI Kecamatan Batang Kuis Kabupaten Deli Serdang Sumatera Utara?

\subsection{Batasan Masalah}

Batasan masalah menurut Arikunto (2016:22) merupakan bagian dari kebutuhan seseorang untuk dipecahkan. Artinya hanya fokus pada ruang lingkup yang teliti sehingga memberikan jawaban terhadap setiap orang yang mencari permasalahan. Mengingat keterbatasan waktu, pengetahuan, serta kemampuan penulis baik secara moril dan materil maka penulis akan membatasi penelitian pada: "Pengaruh Ekspektasi Pendapatan Terhadap Minat Berwirausaha Pada Masyarakat Desa Tumpatan Nibung Dusun VI Kecamatan Batang Kuis Kabupaten Deli Serdang Sumatera Utara". 


\subsection{Tujuan Penelitian}

Tujuan penelitian (2016:39) adalah untuk merumuskan pertanyaan-pertanyaan dan merumuskan jawaban-jawaban terhadap pertanyaan rumusan penelitian tersebut. Adapun yang menjadi tujuan penelitian ini adalah sebagai berikut:

1. Untuk mengetahui pengaruh ekspektasi pendapatan terhadap minat berwirausaha pada masyarakat Desa Tumpatan Nibung Dusun VI Kecamatan Batang Kuis Kabupaten Deli Serdang Sumatera Utara

2. Untuk mengetahui seberapa besar pengaruh ekspektasi pendapatan terhadap minat berwirausaha pada masyarakat Desa Tumpatan Nibung Dusun VI Kecamatan Batang Kuis Kabupaten Deli Serdang Sumatera Utara.

\section{Metode Penelitian}

\subsection{Populasi}

Populasi adalah sekumpulan objek penelitian yang didalamnya terdapat sejumlah data yang diharapkan dapat memberikan keterangan-keterangan yang diperlukan.

Menurut Sugiyono (2016:80) Populasi adalah wilayah generalisasi yang terdiri atas obyek/subyek yang mempunyai kualitas dan karakteristik tertentu yang ditetapkan oleh peneliti untuk dipelajari dan kemudian ditarik kesimpulannya. Dalam penelitian ini yang menjadi populasi adalah masyarakat Desa Tumpatan Nibung Dusun VI Kecamatan Batang Kuis Kabupaten Deli Serdang sebanyak 1.713 jiwa.

\subsection{Sampel}

Sampel adalah kumpulan objek yang merupakan bagian dan populasi, Terdapat dua syarat yang harus dipenuhi dalam prosedur pengambilan sampel, yaitu sampel harus representatif (mewakili), dan besarnya (ukuran) sampel harus memadai. Menurut Sugiyono (2016: 81) sampel adalah sebagian atau wakil dan populasi yang diteliti. Penarikan sampel menggunakan metode random sampling yaitu pengambilan sanggota sampel dari populasi dilakukan secara acak tanpa memperhatikan strata yang ada dalam populasi itu.

\subsection{Uji Normalitas}

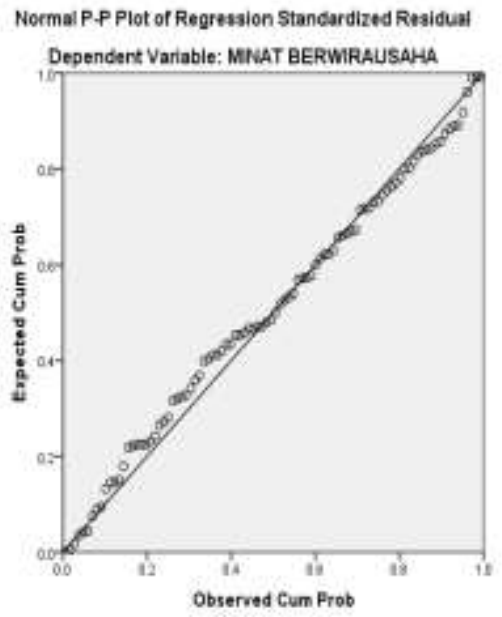

Gambar 1. Normal P-P Plot Histogram

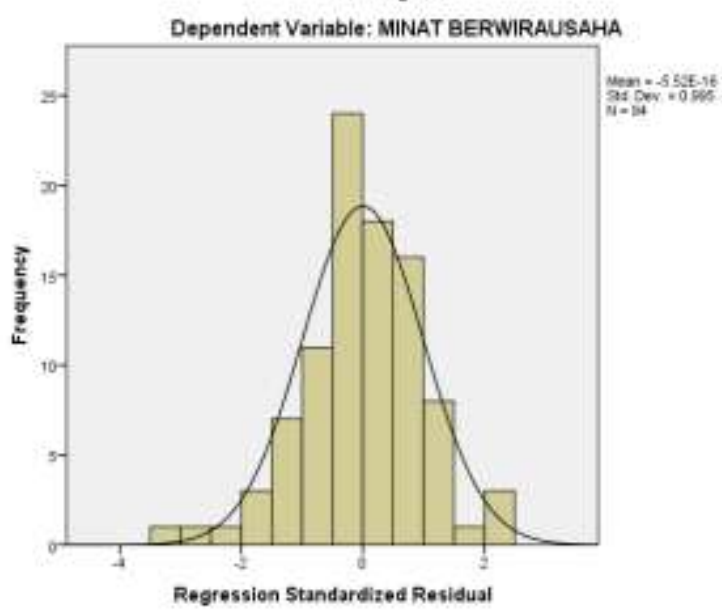

Gambar 2. Histogram

\section{Hasil Dan Pembahasan}

\subsection{Analisis Regresi Berganda}

Analisis regresi linear sederhana dalam penelitian ini bertujuan untuk mengetahui pengaruh antara variabel Ekspektasi Pendapatan (X) terhadap variabel Minat Berwirausaha (Y). Hasil analisis regresi linear sederhana dapat dilihat pada tabel dibawah ini : 
Tabel 1 Hasil Uji Regresi Linear Sederhana Coefficients $^{\mathrm{a}}$

\begin{tabular}{|c|c|c|c|c|c|c|}
\hline \multirow{2}{*}{\multicolumn{2}{|c|}{ Model }} & \multicolumn{2}{|c|}{$\begin{array}{l}\text { Unstandardized } \\
\text { Coefficients }\end{array}$} & $\begin{array}{l}\text { Standardized } \\
\text { Coefficients }\end{array}$ & \multirow[t]{2}{*}{$\mathrm{t}$} & \multirow[t]{2}{*}{ Sig. } \\
\hline & & $\mathrm{B}$ & Std. Error & Beta & & \\
\hline \multirow{2}{*}{1} & (Constant) & 21.684 & 1.822 & \multirow[b]{2}{*}{.721} & 11.900 & \multirow{2}{*}{$\begin{array}{l}.000 \\
.000\end{array}$} \\
\hline & $\begin{array}{l}\text { EKSPEKTASI } \\
\text { PENDAPATAN }\end{array}$ & .479 & .048 & & 9.969 & \\
\hline
\end{tabular}

a. Dependent Variable: MINAT BERWIRAUSAHA

Sumber : Hasil Penelitian, 2021

Dari tabel tersebut diketahui persamaan regresi linear sederhana antara variabel independen dan variabel dependen sebagai berikut :

$$
\mathrm{Y}=\mathbf{2 1 , 6 8 4}+\mathbf{0 , 4 7 9 X}+\mathrm{e}
$$

Dari persamaan regresi tersebut dapat disimpulkan bahwa :

1) Konstanta (a) = 21,684 artinya jika Ekspektasi Pendapatan bernilai 0 maka Minat Berwirausaha pada masyarakat Desa Tumpatan Nibung Dusun VI Kecamatan Batang Kuis Kabupaten Deli Serdang adalah sebesar 21,684.

2) Koefisien regresi variabel Ekspektasi Pendapatan $=0,479$ artinya jika variabel Ekspektasi Pendapatan meningkat sebesar 1 satuan maka variabel Minat Berwirausaha akan meningkat 0,479 .

\subsection{Pengujian Hipotesis \\ 3.2.1. Uji Parsial (Uji t)}

Nilai koefisien regresi dalam persamaan regresi merupakan hasil perhitungan berdasarkan sampel yang dipilih. Pengujian ini dilakukan untuk mengetahui pengaruh variabel bebas terhadap variabel terikat secara parsial. Pengujian melalui uji $t$ adalah dengan membandingkan $t$ hitung. Kriteria pengambilan keputusan adalah : Tingkat kesalahan $(\alpha)=10 \%$ dan derajat kebebasan $(\mathrm{df})=\mathrm{n}$ (jumlah sampel) $-\mathrm{k}$ (jumlah variabel yang digunakan $)=94-2=$ 92, $\mathrm{t}$ tabel $=1,661$

Tabel 2. Hasil Uji Parsial (Uji t)

Coefficients $^{\mathrm{a}}$

\begin{tabular}{|c|c|c|c|c|c|c|}
\hline \multirow{2}{*}{\multicolumn{2}{|c|}{ Model }} & \multicolumn{2}{|c|}{$\begin{array}{c}\text { Unstandardized } \\
\text { Coefficients }\end{array}$} & $\begin{array}{c}\text { Standardized } \\
\text { Coefficients }\end{array}$ & \multirow[t]{2}{*}{$\mathrm{t}$} & \multirow[t]{2}{*}{ Sig. } \\
\hline & & $\mathrm{B}$ & Std. Error & Beta & & \\
\hline \multirow[b]{2}{*}{1} & (Constant) & 21.684 & 1.822 & & 11.900 & .000 \\
\hline & $\begin{array}{l}\text { EKSPEKTASI } \\
\text { PENDAPATAN }\end{array}$ & .479 & .048 & .721 & 9.969 & .000 \\
\hline
\end{tabular}

a. Dependent Variable: MINAT BERWIRAUSAHA

Sumber : Hasil Penelitian, 2021

Berdasarkan tabel di atas, dapat dilihat pengaruh variabel secara parsial sebagai berikut :

a. Berdasarkan analisis regresi diperoleh nilai t hitung sebesar 9,969 > t tabel 1,661 ini berarti variabel Ekspektasi Pendapatan berpengaruh positif terhadap Minat Berwirausaha. Nilai signifikan $0,000>0,05$ ini berarti variabel Ekspektasi Pendapatan signifikan terhadap Minat Berwirausaha.

\subsection{Uji Koefisien Determinasi $\left(\mathbf{R}^{2}\right)$}

Pengujian koefisien determinasi $\left(\mathrm{R}^{2}\right)$ digunakan untuk melihat seberapa besar kontribusi variabel independen terhadap variabel dependen". Semakin besar nilai koefisiensi determinasi maka semakin baik kemampuan variabel $(\mathrm{X})$ menerangkan variabel (Y). Koefisien determinasi ditentukan dengan nilai $R$ Square sebagaimana dapat dilihat pada tabel berikut ini : 
Tabel 3. Hasil Uji Koefisien Determinasi $\left(\mathrm{R}^{2}\right)$

Model Summary $^{\mathrm{b}}$

\begin{tabular}{|l|c|r|r|r|}
\hline Model & $\mathrm{R}$ & $\mathrm{R}$ Square & $\begin{array}{c}\text { Adjusted R } \\
\text { Square }\end{array}$ & $\begin{array}{r}\text { Std. Error of } \\
\text { the Estimate }\end{array}$ \\
\hline 1 & $.721^{\mathrm{a}}$ & .519 & .514 & 3.753 \\
\hline
\end{tabular}
a. Predictors: (Constant), EKSPEKTASI PENDAPATAN
b. Dependent Variable: MINAT BERWIRAUSAHA

Berrdasarkan tabel tersebut, dapat diambil kesimpulan bahwa tingkat pengaruh dari Ekspektasi Pendapatan terhadap Minat Berwirausaha adalah 0,519. Dari hasil perhitungan koefisien determinasi, dapat dijelaskan bahwa Ekspektasi Pendapatan memiliki pengaruh sebesar $51,9 \%$ terhadap Minat Berwirausaha, sementara sisanya sebesar $48,1 \%$ dipengaruhi oleh variabel lain yang berada diluar penelitian.

\section{Hasil Analisa}

\subsection{Pengaruh Ekspektasi Pendapatan Terhadap Minat Berwirausaha}

Ekspesktasi pendapatan merupakan harapan seseorang untuk menghasilkan pendapatan berupa uang dan atau barang yang nantinya digunakan untuk memenuhi berbagai kebutuhan hidup. Zimmerer (2013:12), indikator dari variabel ekspektasi pendapatan adalah pendapatan yang tinggi dan pendapatan tanpa batas. Permasalahan yang terjadi yaitu menurut masyarakat Desa Tumpatan Nibung Dusun VI Kecamatan Batang Kuis Kabupaten Deli Serdang pendapatan dari berwirausaha tergolong rendah dan tidak menentu apalagi usaha yang baru dibangun dari bawah, belum lagi resikonya cukup besar dimana segala bentuk kerugian yang dihadapi akan ditanggung sendiri.

Hasil penelitian ini menyatakan bahwa terdapat pengaruh Ekspektasi Pendapatan terhadap Minat Berwirausaha pada masyarakat Desa Tumpatan Nibung Dusun VI Kecamatan Batang Kuis Kabupaten Deli Serdang. Variabel Ekspektasi Pendapatan memiliki t hitung $>\mathrm{t}$ tabel $(9,969>1,661)$ dan nilai signifikan 0,000 $>0,05$. Sesuai dengan uraian tersebut dapat disimpulkan bahwa Ekspektasi Pendapatan berpengaruh positif dan signifikan terhadap Minat Berwirausaha sehingga hipotesis diterima. Hasil penelitian ini sejalan dengan hasil penelitian yang dilakukan oleh Hadyastiti, dkk. (2020) yang menyatakan bahwa Ekspektasi Pendapatan berpengaruh positif dan signifikan terhadap Minat Berwirausaha.
Hasil perhitungan koefisien determinasi, dapat dijelaskan bahwa Ekspektasi Pendapatan memiliki pengaruh sebesar $51,9 \%$ terhadap Minat Berwirausaha, sementara sisanya sebesar $48,1 \%$ dipengaruhi oleh faktor yang lain yang berada diluar penelitian ini.

\section{Kesimpulan}

Berdasarkan hasil penelitian dan pembahasan dari penelitian yang telah dilakukan mengenai Pengaruh Ekspektasi Pendapatan terhadap Minat Berwirausaha Pada Masyarakat

Desa Tumpatan Nibung Dusun VI Kecamatan Batang Kuis Kabupaten Deli Serdang, maka dapat ditarik kesimpulan sebagai berikut :

1) Ekspektasi Pendapatan berpengaruh positif dan signifikan terhadap Minat Berwirausaha Pada Masyarakat Desa Tumpatan Nibung Dusun VI Kecamatan Batang Kuis Kabupaten Deli Serdang dengan nilai $t$ hitung > t tabel $(9,969>1,661)$ dan nilai signifikan $0,000<0,05$.

2) Hasil perhitungan koefisien determinasi, dapat dijelaskan bahwa Ekspektasi Pendapatan memiliki pengaruh sebesar 51,9\% terhadap Minat Berwirausaha sementara sisanya sebesar $48,1 \%$ dipengaruhi oleh faktor yang lain yang berada diluar penelitian ini.

\section{DAFTAR PUSTAKA}

Buchari Alma. 2013. Manajemen Pemasaran dan Pemasaran Jasa. Bandung: Alfabeta.

Arikunto, Suharsimi. 2016. Prosedur Penelitian: Suatu Pendekatan Praktek. Jakarta: Rineka Cipta.

Azzam, Hamzah. 2016. Pengaruh Ekspektasi Pendapatan, Lingkungan Keluarga dan Pendidikan Kewirausahaan Terhadap Minat Mahasiswa Akuntansi Untuk Berwirausaha. Jurnal Fakultas Ekonomi Universitas Muhammadiyah Jember, Juli 2016.

Boediono. 2012. Pengantar Ekonomi, Jakarta: Erlangga. 
Basrowi. 2014. Kewirausahaan Untuk Perguruan Tinggi. Bogor: Ghalia Indonesia.

Ghozali, Imam. (2011). Aplikasi Analisis Multivariate Dengan Menggunakan Program IBM SPSS. Semarang: Badan Penerbit Universitas Diponegoro.

Scarborough, Norman., Wilson, Doug., Zimmerer, Thomas. 2013. Kewirausahaan Dan Manajemen Usaha Kecil. Jakarta: Salemba empat

Darmadi, Hamid. 2013. Metode Penelitian Pendidikan dan Sosial. Bandung: Alfabeta.

Hadyastiti, Gusti Ayu Made Niken., Suryandari, Ni Nyoman Ayu., dan Putra, Gde Bagus Brahma Putra. 2020. Pengaruh Ekspektasi Pendapatan, Pendidikan Kewirausahaan, Efikasi Diri, Motivasi dan Lingkungan Keluarga Terhadap Minat Berwirausaha. Jurnal Kharisma, Vol. 2 No. 2, Juli 2020, ISSN 2716-2710.

Hidayah, Putri Nur., Sunarto dan Sudarno. 2018. Pengaruh Kreativitas dan Praktik Kerja Industri Terhadap Minat Berwirausaha Siswa Kelas XII Jurusan Pemasaran dan Akuntansi SMK Negeri 3 Sukoharjo Tahun Ajaran 2017/2018. Universitas Sebelas Maret Surakarta.

Munawar, Asep dan Supriatna, Nono. 2018. Pengaruh Sikap dan Motrivasi Terhadap Minat Berwirausaha Siswa. Jurnal Kajian Pendidikan Ekonomi dan Ilmu Ekonomi, ISSN Online: 2549-2284, Volume 2, Nomor 1, Mei 2018.

Muslihudin, Ilmaniati. 2017. Pengaruh Efikasi Diri dan Ekspektasi Pendapatan Terhadap Minat Berwirausaha Siswa SMK (SMK AlMadina). Jurnal Media Teknik dan Sistem Industri. Vol.1 (2017) hal.41-49, ISSN: 2581-0561.

Nitisusastro, Mulyadi. 2012. Perilaku Konsumen Dalam Perspektif Kewirausahaan. Bandung: Alfabeta.

Oktarina, Harti., Agung, Eka Adnan., dan Aswad, Sitti Hajar. 2016. Pengaruh Pendiikan Kewirausahaan,dan Ekspektasi pendapatan Terhadap Minat Berwirausaha Mahasiswa. Phinisi Integration Review Journal, Vol. 3, No.1, Februari 2020 Hal 0106, ISSN: 2614-2317.

Purnamawati, N. K. et al. (2020) 'the Effect of Entrepreneurship Education and Family Environment on Interests Entrepreneurship in Student of the Faculty of Economics, University of Ngurah Rai in Denpasar', $A D I$
Journal on Recent Innovation (AJRI), 1(2), pp. 158-166.

Sanusi, Anwar. 2014. Metode Penelitian Bisnis. Jakarta: PT. Salemba Empat.

Silalahi, Ulber. 2012. Metode Penelitian Sosial. Bandung: Refika Aditama.

Septianti, Dian. 2016. Pengaruh Motivasi, Lingkungan Keluarga dan Ekspektasi Pendapatan Terhadap Minat Berwirausaha (Studi Kasus Pada Mahasiswa Universitas Tridinanti Palembang). Jurnal Ilmiah Ekonomi Global Masa Kini, Volume 7 No.03 Desember 2016, Issn Online : 25022024.

Sugiyono. 2014. Metode Penelitian Kuantitatif, Kualitatif dan $R \& D$. Bandung: PT Alfabet

Sugiyono. 2016. Metode Penelitian Kuantitatif, Kualitatif dan $R \& D$. Bandung: PT Alfabet

Sugiyono. 2018. Metode Penelitian Kuantitatif, Kualitatif dan $R \& D$. Bandung: PT Alfabet

Sugiyono. 2019. Metode Penelitian Kuantitatif, Kualitatif dan $R \& D$. Bandung: PT Alfabet.

Sutejo, B. (2020) 'The Role of Expectations on Income and Self-Concept in Strengthening The Desire to Start Self-Employment', 01(02), pp. 42-45.

Umar, Husein. 2015. Metode Penelitian untuk Skripsi dan Tesis. Jakarta: Rajawali. 